\title{
OCCURRENCE OF MICROTHECA PUNTIGERA (ACHARD) AND MICROTHECA SEMILAEVIS STAL IN FIVE HOSTS IN THE FIELD
}

\section{Farinha, A.O. Menezes Junior, M.U. Ventura, A.Y. Mikami}

Universidade Estadual de Londrina, Departamento de Agronomia, CP 6001, CEP 86051-970, Londrina, PR, Brasil. E-mail: mventura@uel.br

\begin{abstract}
Microtheca punctigera (Achard) (Coleoptera: Chrysomelidae) is a major pest of Brassicaceae family plants in Brazil and occurs together with $M$. semilaevis. Occurrence of larvae and adults of M. punctigera and $M$. semilaevis Stal in five host plants grown in closely patchs was investigated in three periods in the field [Fall/Winter 2001 (May 10 to July 21); Fall 2002 (April 3 to June 12), and Spring 2002 (September 20 to November 15)]. Treatments were Chinese cabbage, mustard, watercress, arrugula and radish. The standard of occurrences of larvae of M. punctigera $+M$. semialevis was not repeated in the three trials: Chinese and mustard were the preferred food in 2001 Fall Winter while in the 2002 Fall and 2002 Spring preference was predominated for mustard and arrugula. M. punctigera was the predominant species during the experiments and populations were higher in the winter periods. In general, M. punctigera beetles were found mostly on Chinese cabbage and mustard, but in some assessments populations were high also in other hosts (mostly arugula). M. semialevis beetles occurred mostly on Chinese cabbage and mustard.
\end{abstract}

KEY WORDS: Chrysomelidae, host preference, assessments, Brassica juncea, Nasturtium officinale, Brassica pekinensis, Eruca sativa, Raphanus sativus.

\section{RESUMO}

OCORRÊNCIA DE MICROTHECA PUNTIGERA (ACHARD) E MICROTHECA SEMILAEVIS STAL EM CINCO HOSPEDEIROS NO CAMPO. Microtheca punctigera (Achard) é praga primária de plantas da família Brassicaceae no Brasil e ocorre associada com M. semilaevis Stal. Ocorrência de larvas e adultos de $M$. punctigera e $M$. semilaevis em cinco plantas hospedeiras em parcelas próximas foi avaliada em três períodos no campo ([outono/inverno, 2001 (10 de maio a 21 de julho); outono, 2002 (3 de abril a 12 de junho), e primavera, 2002 (20 de setembro a 15 de novembro)]. Os tratamentos foram couve chinesa, mostarda, agrião, rúcula e rabanete. O padrão de ocorrência de larva de $M$. punctigera $+M$. semialevis não se repetiu nos três períodos de avaliação: couve chinese e mostarda foram os alimentos preferidos no outono/inverno de 2001, enquanto que no outono e primavera de 2002, mostarda e rúcula foram os hospedeiros preferidos.M. punctigerafoi a espécie predominante durante os experimentos e as populações foram maiores no período de inverno. De maneira geral, besouros de $M$. semialevis foram encontrados principalmente em couve chinesa e mostarda, mas em algumas as avaliações populações foram superiores em outros hospedeiros (principalmente em rúcula). Besouros de $M$. semialevis ocorreram principalmente em couve chinesa e mostarda.

PALAVRAS-CHAVE: Chrysomelidae, preferência hospedeira, levantamento, Brassica juncea, Nasturtium officinale, Brassica pekinensis, Eruca sativa, Raphanus sativus.

\section{INTRODUCTION}

Microtheca punctigera (Achard) is a major pest of Brassicaceae family plants in Brazil. M. semilaevis Stal. is another species referred (MENEZESJunior etal., 2005). Microteca Stal. genus includes multivoltine oligophagous insects that feed exclusively in plants of this family which primary allelochemical is mustard oil glucosides (Hicks, 1974). This species was referred damaging mustard Brassica juncea
Cosson), watercress (Nasturtium officinale L.) (RACCA FiLHO et al., 1994; ZORZENON et al. 1996) and Chinese cabbage [B. pekinensis (Lour.) Rupr.] (MenEZES JunIOR et al., 2005).

In a laboratory multiple-choice assay, isolated larvae of $M$. punctigera preferred mostly Chinese cabbage but groups of larvae preferred mustard and Chinese cabbage. However adults preferred mustard followed by arrugula (Eruca sativa L.) and Chinese cabbage (MenEZes Junior et al., 2005). 
In general, M. punctigera populations in the field arehigh and when control measures were not adopted, crops are completely devastated. This damage potential obligates growers to spray chemical insecticides in plants that are consumed as "greens". Hence occurrence of pesticide residues in these plants is a possibility (MENEzES JunIOR et al., 2005). Neem based insecticides have caused repellent, antifeedant and insecticidal effects on M. punctigera larvae. For organic farming, attempts to control Microtheca Stal. beetles have failed. Intercropping and botanicals insecticides were not efficient strategies for $M$. ochroloma Stal. and M. punctigera in the field (BowERs, 2003) (MiKAMI;VENTURA 2006 personal communication).

Insect feeding preference is an important information for configuring integrated pest management strategies. Studies on feeding preferences of $M$. punctigera are reported just in the laboratory (Menezes Junior et al., 2005). Confining insects in closed environments may reduce behavioral aspects of resistance (RomANow et al., 1991) and results in the laboratory and field may be conflicting. Differences in responses patters of Chrysomelidae beetles in the field and in thelaboratory were reported for cruciferous plants (TAHVANAINEN, 1983). Occurrence of larvae and adult of $M$. punctigera and $M$. semilaevis in five host plants grown in closely patchs was investigated in three periods in the field.

\section{MATERIAL AND METHODS}

Experiment was carried out in the field in the Universidade Estadual de Londrina (UEL) School Farm in three periods, as follows: Fall/Winter 2001 (May 10 to July 21); Fall 2002 (April 3 to June 12), and Spring 2002 (September 20 to November 15). First and second periods were assessed during 11, and third, during 9 weeks. Five treatments were distributed in four stands (blocks) $(0.2 \mathrm{~m}$ height, $1.0 \mathrm{~m}$ width and 8.2 $\mathrm{m}$ length) built with $0.5 \mathrm{~m}$ between then. Treatments were Chinese cabbage, mustard, watercress, arugula and radish (Raphanus sativus L.). Rocket and radish were sown one week before the onset of experiments $(0.2 \times 0.3 \mathrm{~m})$. Chinese cabbage, mustard and watercress were sown 30 days before and transplanted in the onset of the experiments $(0.3 \times 0.3 \mathrm{~m})$. After planting, the soil surface was covered with rice husk to maintain wetness. Plants were weekly irrigated by aspersion when necessary.

Each plot was composed of four lines of five plants. The six central plants composed the useful plot that was weekly assessed. Adults of M. ochroloma and $M$. semilaevis and larvae were counted. Individuals of each species were placed in the Taxonomy facility of the Laboratory of Entomology (Centro de Ciências
Agrárias, Uel). Larvae of both species were assessed together because it was not possible to separate them in the field and the larvae removal tolaboratory would affect next assessments.

Experiments were conducted in a four replicate randomized complete block design. Means and standard error were calculated. Goodman test was used to compare means (CURI, 1997).

\section{RESULTS AND DISCUSSION}

Infestation was higher in the first year winter study (2001) (Fig. 1). Lower number of insects was present in spring of second year replicate trial (2002). In general, M. punctigera have occurred mostly in winter seasons and high populations were reported yet in September (IMENEs et al., 1993). M. ochroloma Stal, which is a closed species to M. punctigera, was referred as cool season beetle (Ameen; Story, 1997a; 1997b). An aestival diapause is referred for Microtheca spp. (JoLIVET, 1951).

Larvae of $M$. punctigera and $M$. semialevis predominate on mustard and mostly Chinesecabbage in the Fall/Winter 2001 trial (Fig. 1) and (Table 1). Larval population peak was found on Chinesecabbage on July 13. In general, when population increased during this season, a greater number of larvae were observed on Chinese cabbage plants. In some assessments, the number of insects on mustard was also greater than the one recorded on arugula, watercress and radish. In the 2002 Fall period, in general, when population increased, on mustard, number of larvae was higher than on other hosts. Number of insects on arugula was higher than watercress, radish (8 assessments) and even in Chinese cabbage (5 times). In the 2002 Spring trial, larvae population on mustard was higher than on arugula (twice) and the other hosts.

M. punctigera was the predominant species during the experiments (Fig. 1 and Table 2). In the Winter 2001, population of M. punctigera beetles was, after the sixth assessment, significantly higher on Chinese cabbage than on other treatments (Fig. 1), (Table 2). However population peak was observed on mustard. Mean number of insects was, in some assessments higher on watercress than on arugula and radish. In the Fall 2002 trial, mustard, Chinese cabbage and arugula were the preferred food by $M$. punctigera beetles, alternating the higher number of insects throughout the season. In the third period (Spring 2002), insects were found in higher numbers on arugula (3 assessments) and afterwards on mustard.

Higher number of M. semialevis beetles werefound mostly on Chinese cabbage and mustard than on the other hosts on some assessments during the three periods evaluated (Fig. 1), (Table 3). 
Larvae

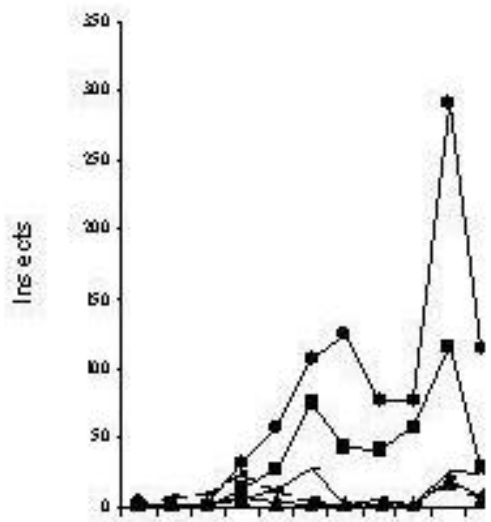

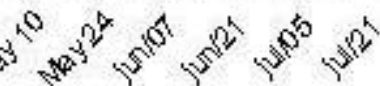

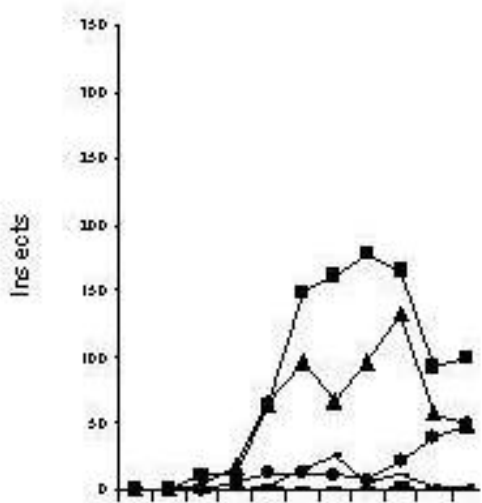

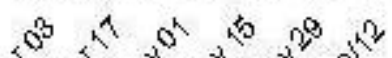
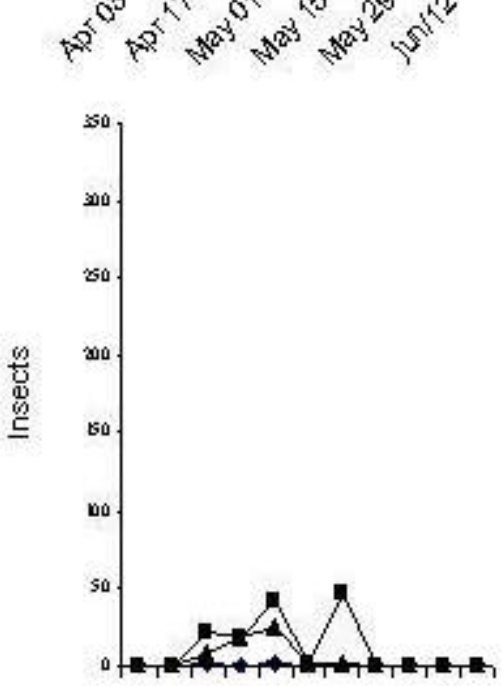

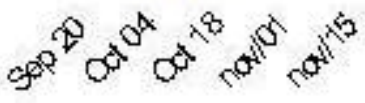

Beetles - M. ochroloma

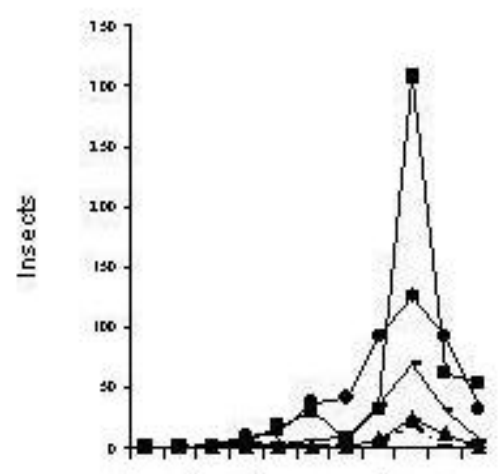

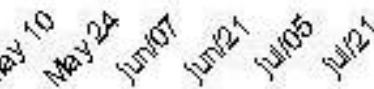

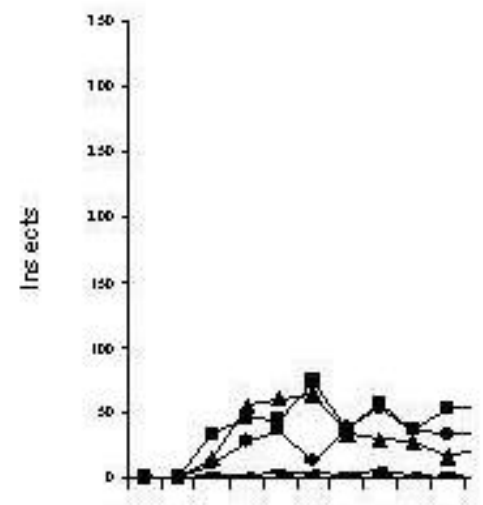

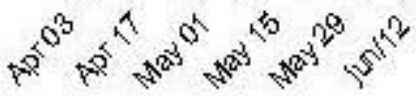

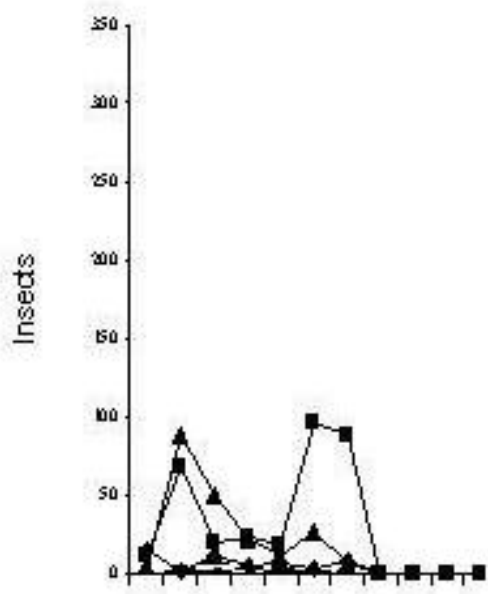

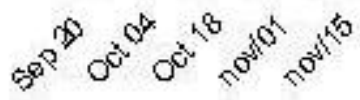

Beetles $-M$ semilavis

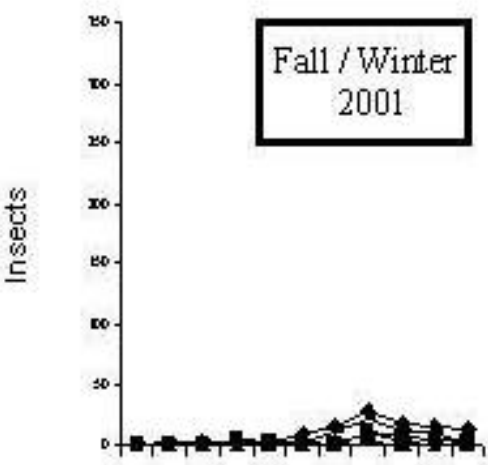

$x^{\circ} \sin ^{2} s^{2} s^{2} s^{2}$

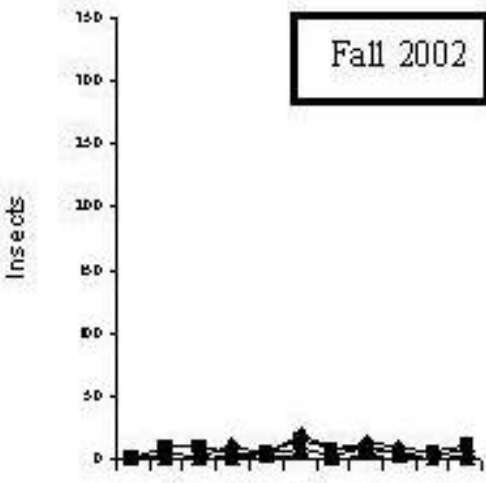

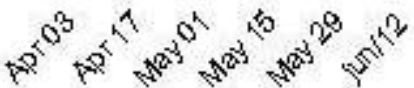

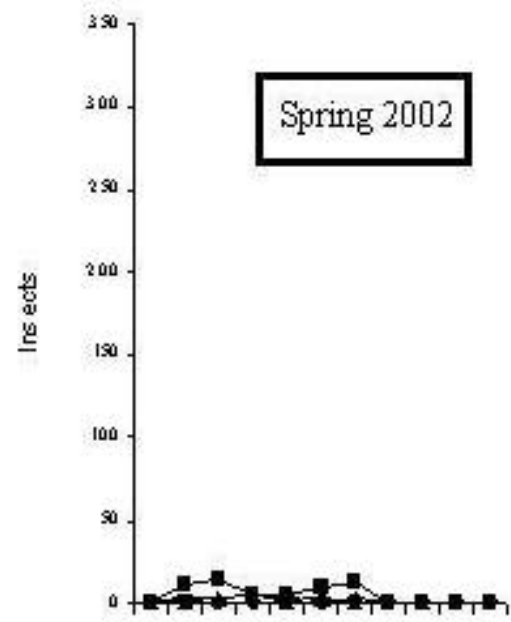

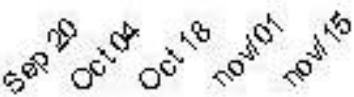

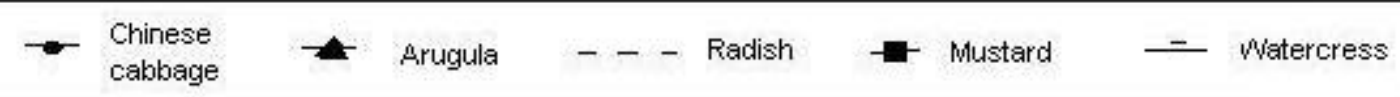

Fig. 1 - Occurrences of larvae and adults of M. punctigera and M. semilaevis in plots of five hosts in the field in three periods. 


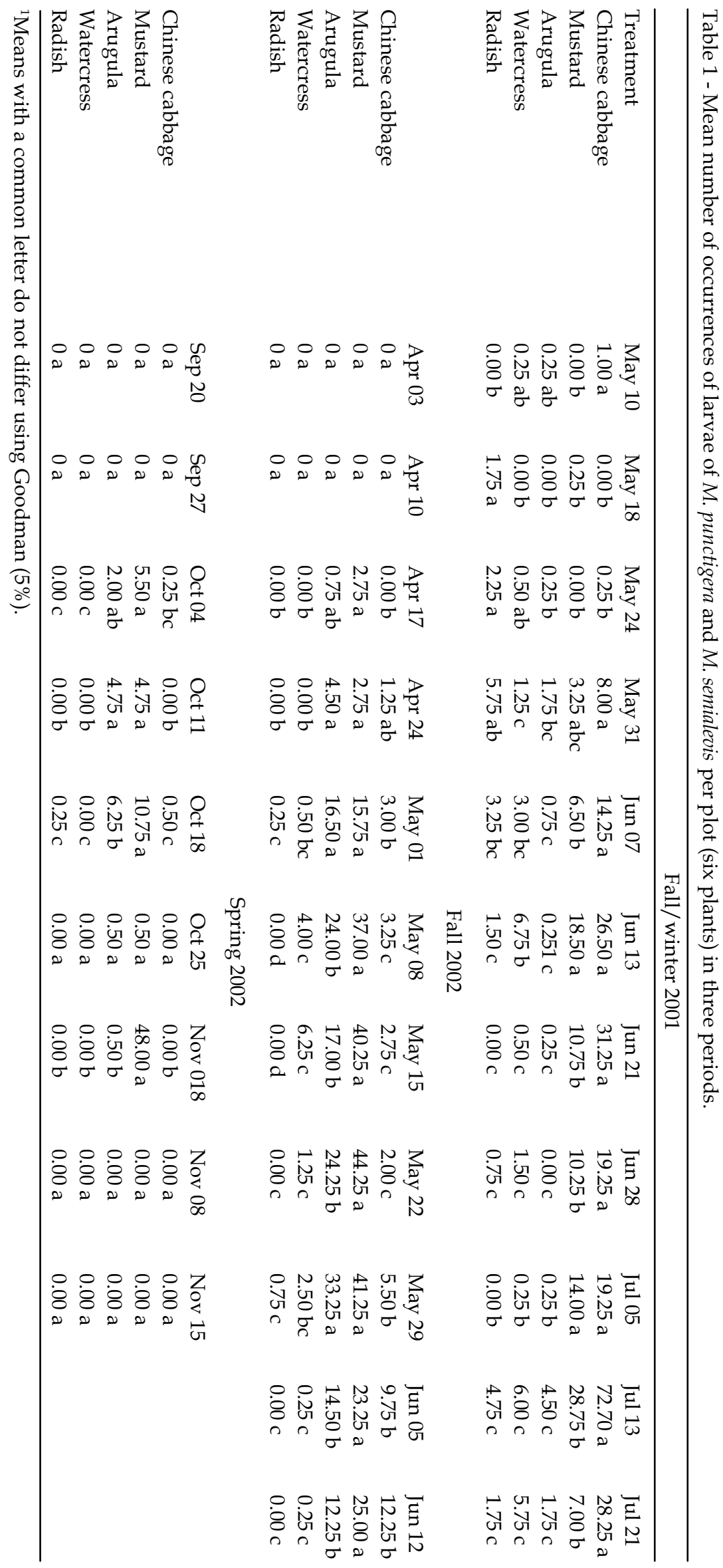




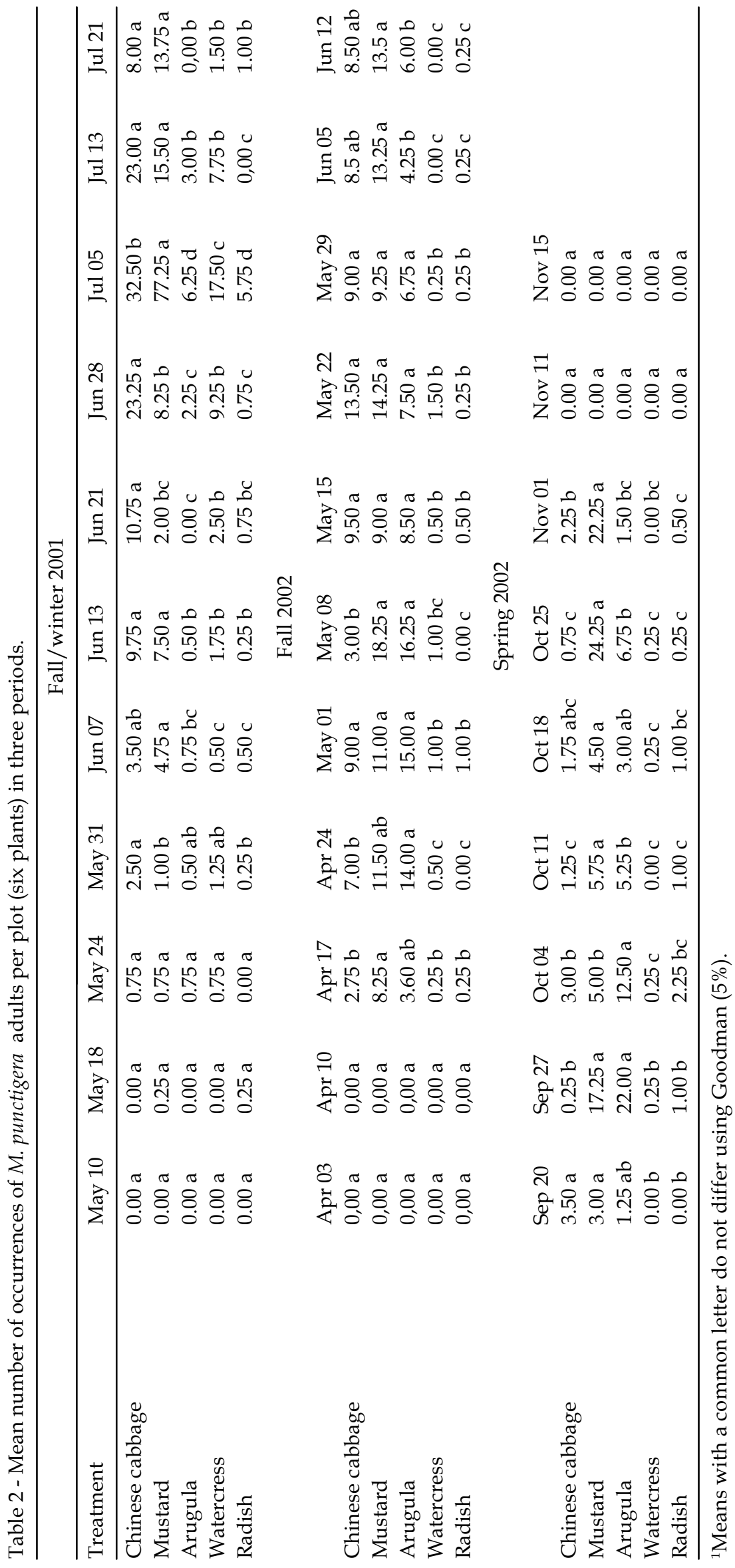




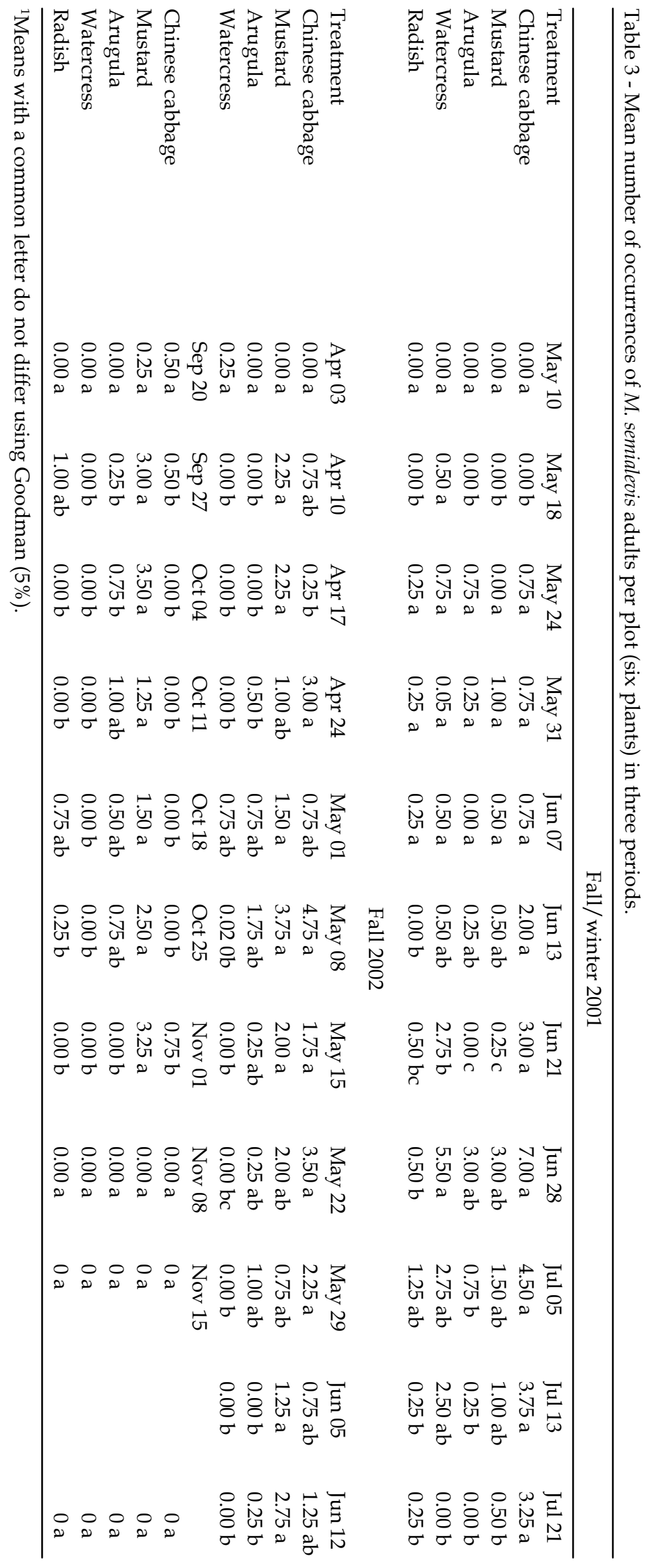


The standard of preference was not repeated in the three trials (Fig. 1), (Table 1). Larvae of M. punctigera + M. semialevis predominated mostly on Chinese and mustard in 2001 Fall/Winter, while in the 2002 Fall and 2002 Spring preference was predominated for mustard and arugula. Hence, the preference may have been influenced by the period of assessment.

In previous laboratory preference assays, Chinese cabbage and mustard were preferred foods for both larvae and adults and arugula was preferred by adults (MENEZES JunIor et al., 2005). In the present study larvae were also found in high numbers in arugula plants.

A series of factors may have affected insect behavior and determined variations in preferences. Gregarious behavior is reported as affecting insect feeding preference (VENTURA et al., 2000) which was also demonstrated for $M$. punctigera in multiple-choice assays in laboratory (MENEZESJunIOR et al.,2005).Feeding and consequent production of excrements affects food quality throughout the season. According to BOWERS (2003), at higher population levels, M. ochroloma move en masse in response to their own herbivory. The author also found that $M$. ochlroloma small populations donot congregate in patch restricted searching.

Population in the field is a consequence of the feeding preference and also of other biotic and abiotic factors. Plant architecture may have great importance inchoosing ahost plant. Chinesecabbageandmustard have leaves that grow in a "closed head". In general, beetles and larvae were sown sheltered in the interior of the head. Ameen; Story (1997a) hypothesized that the texture of host plant leaves may influence feeding; the beetles avoid plants with tough or waxy surfaces.

\section{CONCLUSIONS}

Occurrence of larvae of $M$. punctigera + M. semialevis was affected by the season.

M. punctigera was the predominant species and beetles were found mostly on Chinese cabbage and mustard.

M. semialevis beetles occurred mostly on Chinese cabbage and mustard.

\section{REFERENCES}

AMEEN, A.O.; STORY, R.N. Fecundity and longevity of the yellowmargined leaf beetle (Coleoptera: Chrysomelidae) on crucifers. Journal of Agricultural Entomology, v.14, p.157-162, 1997a.

AMEEN, A.O.; STORY, R.N. Feeding preferences of larval and adult Microtheca ochroloma (Coleoptera: Chrysomelidae) for crucifer foliage. Journal of Agricultural Entomology, v.14, p.363-368, 1997b.
BOWERS, K. Effects of within-field location of host plants and intercropping on the distribution of Microtheca ochroloma (Stål) in mizuna. 2003. 63p. Dissertation (Masters) - Major Departament Natural Resources and Environment, University of Florida, Gainesville, 2003

CURI, P.R. Metodologia e análise da pesquisa em ciências biológicas. Botucatu: Tipomic, 1997. 256p.

HICKS, K.L. Mustard oil glucosides: Feeding stimulants for adult cabbage flea beetles Phyllotreta cruciferae (Coleoptera: Chrysomelidae). Annals of the Entomological Society of America, v.67, p.261-264, 1974.

IMENES, S.D.L.; BERGMAN, E.C.; ZORZENON, F.J.; COELHO, J. Ocorrência de Microtheca punctigela (Achard.) em cultura de agrião. In. REUNIÃO ANUAL DO INSTITUTO BIOLÓGICO, 6., 1993, São Paulo. Resumos. São Paulo, 1993. p.43. Resumos 085.

JOLIVET, P. Contribution à l'étude des Microtheca Stal (Coleoptera Chrysomelidae). Bulletin del Insttitut Royal des Sciences Naturelles de Belgique, v.26, n.48, p.1-27, 1951.

MENEZES JUNIOR., A.O.; MIKAMI, A.Y.; IDE, A.K.; VENTURA, M.U. Feeeding preferences of Microtheca punctigera (Achard) (Colepotera: Chrysomelidae) for some Brassicaceae plants in multiple-choide assays. Scientia Agricola, v.62, n.1, p.72-75, 2005.

RACCA FILHO, G.; RODRIGUES FILHO, I.L.; SANTOS, C.A.C.; RODRIGUES, C.N. Microtheca ochroloma (Coleóptera: Chrysomelidae): aspectos taxonômicos e biológicos. Revista Universidade Rural, v.16, n.1, p.29-35, 1994.

ROMANOW, L.R.; PONTI, O.M.B.; MOLEMA, C. Resistance in tomato to the greenhouse whitefly: Analysis in population dynamics. Entomologia Experimentalis et Applicata, v.60, p.247-259, 1991.

TAHVANAINEN, J. The relationship between flea beetles and their cruciferous host plants: the role of plant and habitats characteristics. Oikos, v.40, n.3, p.433437, 1983.

VENTURA, M.U.; MONTALVÁN, R.; PANIZZI, A.R. Feeding preferences and related types of behaviour of Neomegalotomus parous. Entomologia Experimentalis et Applicata, v.97, p.309-315, 2000.

ZORZENON, F.J.; IMENES, S.D.L.; BERGMANN. E.C.; BOOCK, M.V. Biologia de Microtheca punctigera (Coleóptera: Chrysomelidae). Arquivos do Instituto Biológico, São Paulo, v.63, n.1, p.7-9, 1996.

Received on $9 / 3 / 07$

Accepted on 30/4/09 